\title{
Synthesis and antitubercular evaluation of 7-chloro-4-alkoxyquinoline derivatives
}

\author{
Marcelle de Lima Ferreira Bispo ${ }^{1}$, Laura Nogueira de Faria Cardoso ${ }^{1}$, Maria C. S. Lourenço ${ }^{2}$, Flávio \\ Augusto Ferreira Martins Bezerra ${ }^{2}$, Rodrigo Pedro Pinto Soares ${ }^{3}$, Caryne Margotto Bertollo ${ }^{3}$, Marcus \\ Vinícius Nora de Souza ${ }^{1 *}$
}

${ }^{1}$ Fundação Oswaldo Cruz, Instituto de Tecnologia em Fármacos-Far Manguinhos, 21041-250, Rio de Janeiro, RJ, Brazil.

${ }^{2}$ Fundação Oswaldo Cruz, Instituto de Pesquisas Clínicas Evandro Chagas, Departamento de Bacteriologia, Av. Brasil, 4365, Manguinhos, Rio de Janeiro, Brazil

${ }^{3}$ Fundação Oswaldo Cruz, Centro de Pesquisas René Rachou, Laboratório de Biomarcadores de Diagnóstico e Monitoração, Av. Augusto de Lima, 1715

Barro Preto, 30190-002, Belo Horizonte, MG, Brazil

\begin{abstract}
A series of eight 7-chloro-4-alkoxyquinoline derivatives (2a-h) have been synthesized and their in vitro (antimycobacterial) activity against Mycobacterium tuberculosis was evaluated. Furthermore, all the active compounds were selected for evaluation of their cytotoxicities against the human hepatoma (HepG2) and the relative selectivity (selective index) of these compounds against $M$. tuberculosis compared to HepG2 was calculated based on $\mathrm{MLD}_{50} / \mathrm{MIC}$ ratios. These biological results have been compared to a series of 7-chloro-4aminoquinoline derivatives 1a-i, previously identified by our research group with the aim to provide important information about the structure-activity relationship of quinoline derivatives.
\end{abstract}

Keywords: quinolone; tuberculosis; antimycobacterial activity; cytoxicity assays.

\section{Introduction}

The development of antibiotic therapies that overcome the emerging antimicrobial resistance of Mycobacterium tuberculosis strains is one of the major challenges to control the tuberculosis (TB). There are two types of resistance recognized by World Health Organization (WHO): multidrug-resistant tuberculosis (MDR-TB, resistant to at least isoniazid or rifampicin, with or without resistance to other first-line drugs) and extensively drug-resistant TB (XDR-TB, is MDR-TB that is also resistant to any fluoroquinolone and also to any of the three second-line injectables-amikacin, capreomycin, and kanamycin). WHO estimates that there are about 450,000 MDR-TB cases in the world in 2012 and about $10 \%$ of MDR-TB cases worldwide have XDR-TB. Besides, the presence of XDR-TB strains has been reported at least once in 92 countries worldwide by the end of $2012^{1}$.

*Corresponding author: Vinícius Nora de Souza

E-mail address: marcos_souza@far.fiocruz.br

DOI: http://dx.doi.org/10.13171/mjc.4.1.2015.19.02.10.18/desouza 
Considering the high impact of resistant strains for the tuberculosis treatment, there is an urgent requirement of developing new drugs to treat this disease efficiently. Therefore, in previous studies conducted by our research program for the development of new anti-TB agents, we have prepared and evaluated a series of 7-chloro-4-aminoquinoline derivatives 1a-i, among them, three compounds (1b-d) have been interesting antimycobacterial activities. In this previous report, the study of structure-activity relationship of this class of compounds pointed out that the presence of the chlorine at $\mathrm{C} 7$ position and the increase of the lipophilicity are significant features for the biological activity ${ }^{2}$. Considering these results, we decided to continue studying the potential of quinoline derivatives as anti-TB agents through the synthesis and antitubercular evaluation of a series of 7-chloro-4-alkoxyquinoline derivatives 2a-h. These compounds were designed by a classic isosteric replacement (NH x O). Besides, the selection of the substituents attached at oxygen atom was based on the best biological results obtained in the previous series of 7-chloro-4-aminoquinoline derivatives 1a-i and also in order to increase the lipophilicity and the molecular surface. Furthermore, the relevance of this report also arises from the need of ongoing researches on the structure-activity relationship of quinoline derivatives (Figure $\mathbf{1})^{3}$.

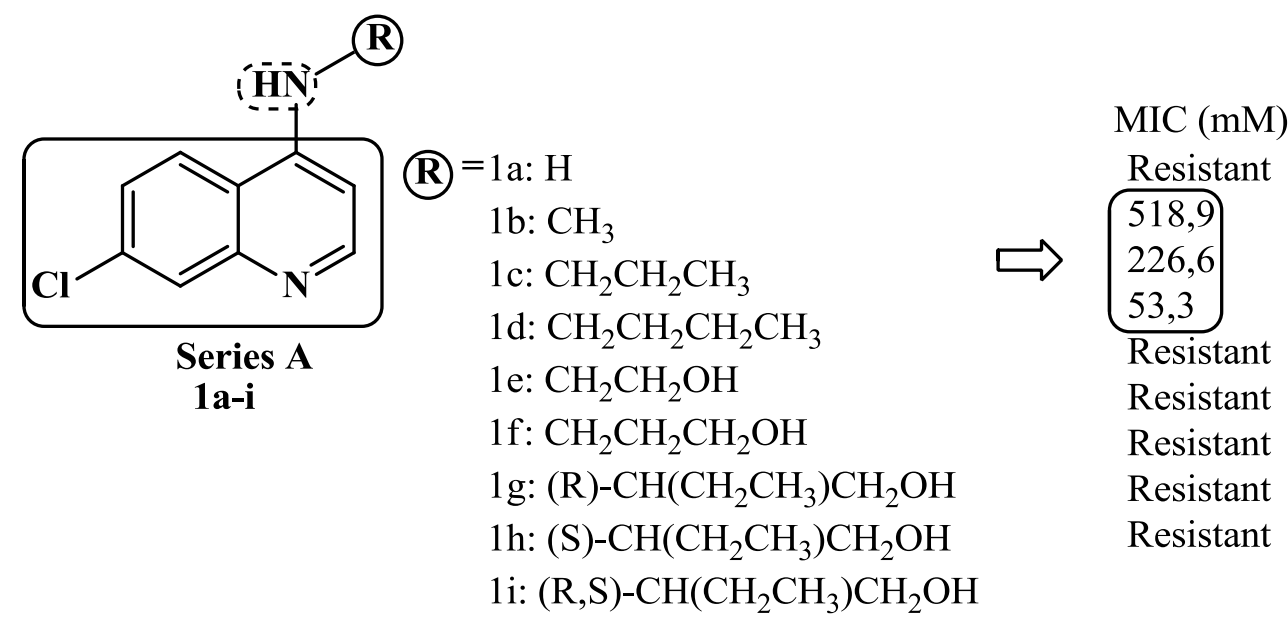

\section{Molecular Design}

Important molecular features identified by previous SAR Molecular modification (isosteric replacement)

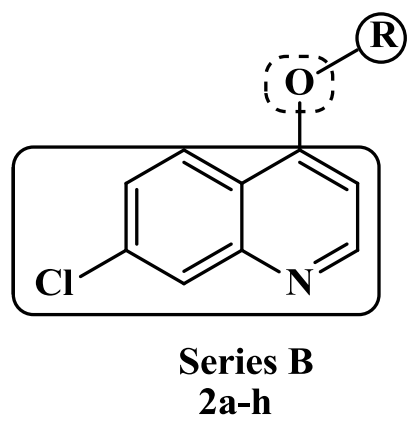

$$
\begin{aligned}
& \text { (R) }=2 \mathrm{a}: \mathrm{CH}_{3} \\
& \text { 2b: } \mathrm{CH}_{2} \mathrm{CH}_{3} \\
& \text { 2c: } \mathrm{CH}_{2} \mathrm{CH}_{2} \mathrm{CH}_{3} \\
& \text { 2d: } \mathrm{CH}_{2} \mathrm{CH}_{2} \mathrm{CH}_{2} \mathrm{CH}_{3} \\
& \text { 2e: } \mathrm{CH}\left(\mathrm{CH}_{3}\right)_{2} \\
& \text { 2f: } \mathrm{CH}_{2} \mathrm{CH}\left(\mathrm{CH}_{3}\right)_{2} \\
& \text { 2g: } \mathrm{CH}\left(\mathrm{CH}_{3}\right) \mathrm{CH}_{2} \mathrm{CH}_{3} \\
& \text { 2h: } \mathrm{CH}_{2} \mathrm{CH}=\mathrm{CHCH}_{3}
\end{aligned}
$$

Figure 1. Molecular design of 7-chloro-4-alkoxyquinoline derivatives (2a-h). 


\section{Experimental Section}

\section{General Procedures}

Melting points were determined on a Buchi apparatus and are uncorrected. Infrared spectra were recorded on a Thermo Nicolet Nexus 670 spectrometer as potassium bromide pellets and frequencies are expressed in $\mathrm{cm}^{-1}$. Mass spectra (ESI assay in solution of ammonium chloride) were recorded on Micromass ZQ Waters mass spectrometer. LTQ Orbitrap XL ETD (mass spectrometry facility RPT02H PDTIS/Carlos Chagas InstituteFiocruz Parana). NMR spectra were recorded on a Bruker Avance 400 operating at $400 \mathrm{MHz}$ $\left({ }^{1} \mathrm{H}\right)$ and $100.0 \mathrm{MHz}\left({ }^{13} \mathrm{C}\right)$ and Bruker Avance 500 spectrometer operating at $500 \mathrm{MHz}\left({ }^{1} \mathrm{H}\right)$ and $125 \mathrm{MHz}\left({ }^{13} \mathrm{C}\right)$, in deuterated dimethylsulfoxide. Chemical shifts are reported in ppm $(\delta)$ relative to tetramethylsilane and $J$-coupling in Hertz $(\mathrm{Hz})$. Proton and carbon spectra were typically obtained at room temperature. For TLC plates coated with silica gel were run in chloroform/methanol mixture and spots were developed in ultraviolet.

\section{General procedures of synthesis of 7-chloro-4-alkoxyquinoline}

Metallic sodium $(0.172 \mathrm{~g}, 7.48 \mathrm{mmol})$ was slowly added in the appropriate alcohol (15.0 mL, 468-202 mmol). After the complete dissolution of sodium, 4,7 dichloroquinoline $(0.3 \mathrm{~g}, 1.51 \mathrm{mmol})$ was added in the solution and the mixture was stirred for $8-72 \mathrm{~h}$ at the boiling point of the corresponding alcohol. Besides, the excess of solvent was concentrated under reduced pressure and the residue was extracted with water $(15 \mathrm{~mL})$ and extracted with ethyl acetate $(3 \times 15 \mathrm{~mL})$. The combined organic phases were dried over $\mathrm{Na}_{2} \mathrm{SO}_{4}$ and concentrated under reduced pressure. After that, some desired products were obtained pure (1-3 and 5) or the crude products were purified by different process according to the substituent attached to oxygen (see bellow; 4 and 6-9) to afford the pure derivatives $2 \mathbf{a - i}$ as pale yellow or white solids in $60-95 \%$ yields.

\section{7-chloro-4-methoxyquinoline (2a)}

Yield: $95 \%$. m.p. $137-138^{\circ} \mathrm{C}^{4} .{ }^{1} \mathrm{H}$ NMR (400 MHz; DMSO-d6): $\delta: 8.76(1 \mathrm{H}, \mathrm{d}$, $J=4.1 \mathrm{~Hz}, \mathrm{H}-2) ; 8.15(1 \mathrm{H}, \mathrm{d}, J=7.1 \mathrm{~Hz}, \mathrm{H}-5) ; 8.00(1 \mathrm{H}, \mathrm{d}, J=1.5 \mathrm{~Hz}, \mathrm{H}-8) ; 7.59(1 \mathrm{H}, \mathrm{dd}$, $J=7.2$ and $1.6 \mathrm{~Hz}, \mathrm{H}-6) ; 7.08$ (1H, d, $J=4.2 \mathrm{~Hz}, \mathrm{H}-3) ; 4.06$ (3H, s, H-2').

${ }^{13} \mathrm{C}$ NMR (100 MHz; DMSO-d6): $\delta 161.6$ (C-4); 153.1 (C-2); 149.1 (C-4a); 134.4 (C-7); 127.3 (C-8); 126.3 (C-5); 123.7 (C-6); 119.3 (C-8a); 101.6 (C-3); 56.3 (C-2').

MS/ESI: $[\mathrm{M}+\mathrm{H}]:$ 193.0. IR $v_{\max }\left(\mathrm{cm}^{-1} ; \mathrm{KBr}\right.$ pellets): 1124 (C-O stretching vibration).

\section{7-chloro-4-ethoxyquinoline (2b)}

Yield: $82 \%$. m.p. $98-99^{\circ} \mathrm{C}^{5} .{ }^{1} \mathrm{H}$ NMR (400 MHz; DMSO-d6): $\delta: 8.75(1 \mathrm{H}, \mathrm{d}, J=5.2 \mathrm{~Hz}$, $\mathrm{H}-2) ; 8.16(1 \mathrm{H}, \mathrm{d}, J=8.9 \mathrm{~Hz}, \mathrm{H}-5) ; 7.99(1 \mathrm{H}, \mathrm{d}, J=2.0 \mathrm{~Hz}, \mathrm{H}-8) ; 7.59(1 \mathrm{H}, \mathrm{dd}, J=8.9$ and $2.1 \mathrm{~Hz}, \mathrm{H}-6) ; 7.05(1 \mathrm{H}, \mathrm{d}, J=5.3 \mathrm{~Hz}, \mathrm{H}-3) ; 4.32(2 \mathrm{H}, \mathrm{q}, J=7.0 \mathrm{~Hz}, \mathrm{H}-2$ '); $1.48(3 \mathrm{H}, \mathrm{t}, J=$ $\left.7.0 \mathrm{~Hz}, \mathrm{H}-3{ }^{\prime}\right) .{ }^{13} \mathrm{C}$ NMR (100 MHz; DMSO-d6): $\delta 160.7$ (C-4); 153.1 (C-2); 149.2 (C-4a); 134.3 (C-7); 127.3 (C-8); 126.2 (C-5); 123.8 (C-6); 119.4 (C-8a); 102.1 (C-3); 64.4 (C-2'); 14.2 (C-3'). MS/ESI: [M+H]: 208.2. IR $v_{\max }\left(\mathrm{cm}^{-1}\right.$; KBr pellets): 1123 (C-O stretching vibration).

\section{7-chloro-4-propoxyquinoline (2c)}

Yield: $75 \%$. m.p. $70-71^{\circ} \mathrm{C} .{ }^{1} \mathrm{H}$ NMR $(500 \mathrm{MHz}$; DMSO-d6): $\delta: 8.75(1 \mathrm{H}, \mathrm{d}, J=5.2 \mathrm{~Hz}$, $\mathrm{H}-2) ; 8.16(1 \mathrm{H}, \mathrm{d}, J=8.9 \mathrm{~Hz}, \mathrm{H}-5) ; 7.99(1 \mathrm{H}, \mathrm{d}, J=1.8 \mathrm{~Hz}, \mathrm{H}-8) ; 7.59(1 \mathrm{H}, \mathrm{dd}, J=8.9$ and $1.9 \mathrm{~Hz}, \mathrm{H}-6) ; 7.05(1 \mathrm{H}, \mathrm{d}, J=5.2 \mathrm{~Hz}, \mathrm{H}-3) ; 4.21(2 \mathrm{H}, \mathrm{t}, J=6.4 \mathrm{~Hz}, \mathrm{H}-2$ '); 1.89 (2H, sx, $J=7.1$ and $\left.6.8 \mathrm{~Hz}, \mathrm{H}-3^{\prime}\right) 1.07$ (3H, t, $\left.J=7.4 \mathrm{~Hz}, \mathrm{H}-4^{\prime}\right) .{ }^{13} \mathrm{C}$ NMR (125 MHz, DMSO-d6) $\delta$ : 
160.9 (C-4); 153.1 (C-2); 149.2 (C-4a); 134.4 (C-7); 127.3 (C-8); 126.2 (C-5); 123.8 (C-6); 119.4 (C-8a); 102.1 (C-3); 70.0 (C-2'); 21.8 (C-3'); 10.4 (C-4'). MS/ESI: [M+H]: 222.0. IR $v_{\max }\left(\mathrm{cm}^{-1} ; \mathrm{KBr}\right.$ pellets): 1117 (C-O stretching vibration).

\section{4-butoxy-7-chloroquinoline (2d)}

Yield: $62 \%$. m.p. $56-57^{\circ} \mathrm{C} .{ }^{1} \mathrm{H}$ NMR (400 MHz; DMSO-d6): $\delta: 8.75(1 \mathrm{H}, \mathrm{d}, J=4.2 \mathrm{~Hz}$, $\mathrm{H}-2) ; 8.16(1 \mathrm{H}, \mathrm{d}, J=7.1 \mathrm{~Hz}, \mathrm{H}-5) ; 7.98(1 \mathrm{H}, \mathrm{d}, J=1.5 \mathrm{~Hz}, \mathrm{H}-8) ; 7.59(1 \mathrm{H}, \mathrm{dd}, J=7.1$ and $1.6 \mathrm{~Hz}, \mathrm{H}-6) ; 7.06(1 \mathrm{H}, \mathrm{d}, J=4.2 \mathrm{~Hz}, \mathrm{H}-3) ; 4.26\left(2 \mathrm{H}, \mathrm{t}, J=5.1 \mathrm{~Hz}, \mathrm{H}-2{ }^{\prime}\right) ; 1.85$ (2H, qi, $\left.J=5.6 \mathrm{~Hz} \mathrm{H}-3^{\prime}\right) ; 1.54\left(2 \mathrm{H}, \mathrm{sx}, J=6.0 \mathrm{~Hz}, \mathrm{H}-4^{\prime}\right) ; 0.98\left(3 \mathrm{H}, \mathrm{t}, J=5.9 \mathrm{~Hz}, \mathrm{H}-5^{\prime}\right)$.

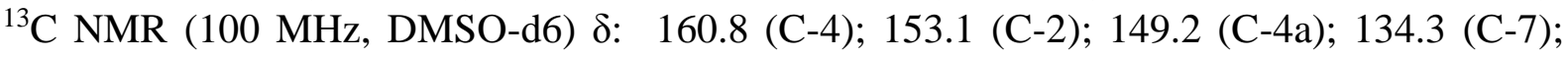
127.2 (C-8); 126.2 (C-5); 123.7 (C-6); 119.4 (C-8a); 102.0 (C-3); 68.2 (C-2'); 30.3 (C-3'); 18.8 (C-4'); 13.6 (C-5'). HRMS/ESI: [M+H]: 236.0834. IR $v_{\max }\left(\mathrm{cm}^{-1} ; \mathrm{KBr}\right.$ pellets): 1119 (C-O stretching vibration).

\section{7-chloro-4-isopropoxyquinoline (2e)}

Purification by chromatography column (hexane / ethyl acetate (8:2).Yield: $60 \%$. ${ }^{1} \mathrm{H}$ NMR (500 MHz; DMSO-d6): $\delta: 8.66(1 \mathrm{H}, \mathrm{d}, J=5.5 \mathrm{~Hz}, \mathrm{H}-2) ; 8.20(1 \mathrm{H}, \mathrm{d}, J=8.9 \mathrm{~Hz}, \mathrm{H}-$ 5); $7.90(1 \mathrm{H}, \mathrm{d}, J=2.0 \mathrm{~Hz}, \mathrm{H}-8) ; 7.51(1 \mathrm{H}, \mathrm{dd}, J=8.9$ and $2.1 \mathrm{~Hz}, \mathrm{H}-6) ; 7.01(1 \mathrm{H}, \mathrm{d}$, $J=5.5 \mathrm{~Hz}, \mathrm{H}-3)$; 4.98 (1H, sp, H-2'); 1.49 (6H, d, $J=6.1 \mathrm{~Hz}, \mathrm{H}-3$ ' and H-4'). ${ }^{13} \mathrm{C}$ NMR (125

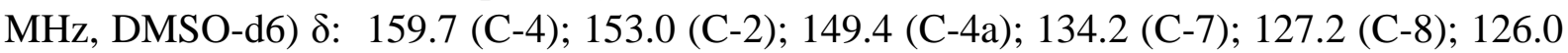
(C-5); 123.9 (C-6); 119.8 (C-8a); 102.6 (C-3); 70.9 (C-2'); 21.4 (C-3' and C-4'). MS/ESI: $[\mathrm{M}+\mathrm{H}]: 222.0$. IR $v_{\max }\left(\mathrm{cm}^{-1} ; \mathrm{KBr}\right.$ pellets): 1118 (C-O stretching vibration).

\section{7-chloro-4-isobutoxyquinoline (2f)}

The crude product was purified by washing with cold hexane $(3 \times 10 \mathrm{~mL})$.

Yield: 67\%. m.p. 56-58 ${ }^{\circ} \mathrm{C} .{ }^{1} \mathrm{H}$ NMR (400 MHz; DMSO-d6): $\delta: 8.74(1 \mathrm{H}, \mathrm{d}, J=5.2 \mathrm{~Hz}, \mathrm{H}-$ 2); $8.18(1 \mathrm{H}, \mathrm{d}, J=9.2 \mathrm{~Hz}, \mathrm{H}-5) ; 7.99(1 \mathrm{H}, \mathrm{d}, J=2.0 \mathrm{~Hz}, \mathrm{H}-8) ; 7.60(1 \mathrm{H}, \mathrm{dd}, J=8.8$ and 2.0 Hz, H-6); 7.05 (1H, d, $J=5.2 \mathrm{~Hz}, \mathrm{H}-3)$; 4.04 (2H, d, $J=6.4 \mathrm{~Hz}, \mathrm{H}-2$ '); 2.21-2.17 (1H, m, H$\left.3^{\prime}\right) ; 1.07$ (6H, d, $J=6.8 \mathrm{~Hz}$; H-4' and H-5'). ${ }^{13} \mathrm{C}$ NMR (100 MHz, DMSO-d6) $\delta$ : 160.8 (C4); 153.0 (C-2); 149.1 (C-4a); 134.3 (C-7); 127.2 (C-8); 126.2 (C-5); 123.6 (C-6); 119.4 (C8a); 102.0 (C-3); 74.3 (C-2'); 39.6 (C-1'); 27.5 (C-3'); 18.9 (C-4'). HRMS/ESI: [M+H]: 236.0833. IR $v_{\max }\left(\mathrm{cm}^{-1} ; \mathrm{KBr}\right.$ pellets): 1120 (C-O stretching vibration).

\section{4-sec-butoxy-7-chloroquinoline (2g)}

Purification by chromatography column (hexane / ethyl acetate (8:2). Yield: $74 \%$. ${ }^{1} \mathrm{H}$ NMR (400 MHz; DMSO-d6): $\delta: 8.74(1 \mathrm{H}, \mathrm{d}, J=6.6 \mathrm{~Hz}, \mathrm{H}-2) ; 8.16(1 \mathrm{H}, \mathrm{d}, J=11.1 \mathrm{~Hz}$, $\mathrm{H}-5) ; 7.98(1 \mathrm{H}, \mathrm{d}, J=2.6 \mathrm{~Hz}, \mathrm{H}-8) ; 7.57(1 \mathrm{H}, \mathrm{dd}, J=11.1$ and $2.6 \mathrm{~Hz}, \mathrm{H}-6) ; 7.07(1 \mathrm{H}, \mathrm{d}$, $J=6.7 \mathrm{~Hz}, \mathrm{H}-3) ; 4.77\left(1 \mathrm{H}, \mathrm{q}, \mathrm{J}=7.4 \mathrm{~Hz}, \mathrm{H}-2^{\prime}\right) ; 1.86-1.73(2 \mathrm{H}, \mathrm{m}, \mathrm{H}-3$ ') $) 1.38$ (3H, d, $J=7.6$ $\mathrm{Hz}, \mathrm{H}-5$ '); 0.98 (3H, t, $\left.J=9.2 \mathrm{~Hz}, \mathrm{H}-4^{\prime}\right) .{ }^{13} \mathrm{C}$ NMR (100 MHz, DMSO-d6) $\delta: 160.0$ (C-4); 153.0 (C-2); 149.4 (C-4a); 134.3 (C-7); 127.2 (C-8); 126.0 (C-5); 123.9 (C-6); 119.9 (C-8a); 118.2 (C-3); 102.6 (C-3); 75.5 (C-2'); 28.3 (C-5'); 18.5 (C-3'); 9.3 (C-4'). HRMS/ESI: $[\mathrm{M}+\mathrm{H}]: 236.0834$. IR $v_{\max }\left(\mathrm{cm}^{-1} ; \mathrm{KBr}\right.$ pellets): 1116 (C-O stretching vibration).

\section{7-chloro-4-[(1E)-prop-1-en-1-yloxy]quinoline (2h)}

The crude product was purified by recrystallization using hexane as the solvent.

Yield: $65 \%$. m.p. $68-70^{\circ} \mathrm{C} .{ }^{1} \mathrm{H}$ NMR $(500 \mathrm{MHz}$; DMSO-d6): $\delta 8.75(1 \mathrm{H}, \mathrm{d}, J=5.3 \mathrm{~Hz}$, $\mathrm{H}-2) ; 8.16(1 \mathrm{H}, \mathrm{d}, J=8.9 \mathrm{~Hz}, \mathrm{H}-5) ; 7.99(1 \mathrm{H}, \mathrm{d}, J=2.0 \mathrm{~Hz}, \mathrm{H}-8) ; 7.57(1 \mathrm{H}, \mathrm{dd}, J=11.0$ and $2.1 \mathrm{~Hz}, \mathrm{H}-6) ; 7.05(1 \mathrm{H}, \mathrm{d}, J=5.3 \mathrm{~Hz}, \mathrm{H}-3) ; 5.86-5.78(1 \mathrm{H}, \mathrm{m}, \mathrm{H}-3$ '); $4.78(2 \mathrm{H}, \mathrm{d}, J=6.0 \mathrm{~Hz}$, $\left.\mathrm{H}^{\prime}{ }^{\prime}\right) ; 1.76\left(3 \mathrm{H}, \mathrm{dd}, J=6.0\right.$ and $5.0 \mathrm{~Hz}, \mathrm{H}-5$ ') $1.66\left(1 \mathrm{H}, \mathrm{d}, J=5.3 \mathrm{~Hz}, \mathrm{H}-4^{\prime}\right) .{ }^{13} \mathrm{C} \mathrm{NMR}$ (125 MHz, DMSO-d6) $\delta: 160.5$ (C-4); 153.0 (C-2); 149.2 (C-4a); 134.3 (C-7); 131.0 (C-2'); 
127.2 (C-8); 126.2 (C-5); 123.8 (C-6); 119.4 (C-8a); 102.4 (C-3'); 17.6 (C-4'). HRMS/ESI: [M-H]: 233.0672. IR $v_{\max }\left(\mathrm{cm}^{-1} ; \mathrm{KBr}\right.$ pellets): 1115 (C-O stretching vibration).

\section{General procedures for biological tests}

\section{Antimycobacterial Activity}

Briefly, $200 \mu \mathrm{L}$ of sterile deionized water was added in all outer-perimeter wells of sterile 96 well plates (falcon, 3072: Becton Dickinson, Lincoln Park, NJ) to minimize evaporation of the medium in the test wells during incubation. The 96 plates received $100 \mu \mathrm{L}$ of the Middlebrook $7 \mathrm{H} 9$ broth containing the mycobacterial cells (Difco laboratories, Detroit, MI, USA) and a serial dilution of the compounds (2a-i) was made directly on the plate. The final drug concentrations tests were $0.01-100 \mu \mathrm{g} / \mathrm{mL}$. Plates were covered and sealed with parafilm and incubated at $37^{\circ} \mathrm{C}$ for five days. After this time, $25 \mu \mathrm{L}$ of a freshly prepared $1: 1$ mixture of Alamar Blue (Accumed International, Westlake, Ohio) reagent and 10\% tween 80 was added in plate and incubated for $24 \mathrm{~h}$. A blue color in the well was interpreted as no bacterial growth, and a pink color was scored as growth. The MIC (minimal inhibition concentration) was defined as the lowest drug concentration, which prevented a color change from blue to pink. Ethambutol (EMB) was used by pattern in the tests.

\section{Cell Viability Assay}

Cytotoxicity was determined using the MTT method (3-(4,5-dimethylthiazol-2-yl)2,5-diphenyl tetrazolium bromide) and the hepatoma cell lineage Hep G2 A16. Cells were kept in RPMI medium supplemented with $10 \%$ FBS and confluent monolayers were trypsinized, washed in RPMI and applied in 96-well microtiter plates ( 4 X $10^{4}$ cells/well). Compounds and amphotericin $\mathrm{B}$ in the same conditions described above were incubated with the cells $\left(37^{\circ} \mathrm{C}, 5 \% \mathrm{CO}_{2}, 24 \mathrm{~h}\right)$. Colorimetric reaction was developed after incubation with MTT $\left(37^{\circ} \mathrm{C}, 4 \mathrm{~h}\right)$ followed by addition of acidified isopropanol as previously described ${ }^{5}$. The reaction was read spectrophotometrically with a $570 \mathrm{~nm}$ filter and a background of $630 \mathrm{~nm}$. Incubations were tested in triplicate in two independent experiments.

\section{Results and Discussion}

The synthesis of 7-chloro-4-alkoxyquinoline derivatives (2a-h) was performed through reactions between 4,7-dichloroquinoline and a solution of the alkoxyde in the corresponding alcohol as a solvent, under the appropriated reflux temperature, as indicated in Scheme $\mathbf{1}$ and Table 1.<smiles>Clc1ccc2c(Cl)ccnc2c1</smiles><smiles>[R]Oc1ccnc2cc(Cl)ccc12</smiles>

Scheme 1. Preparation of 7-chloro-4-alkoxyquinoline derivatives (2a-h). 
Table 1. Yields, reaction times and melting points of 7-chloro-4-alkoxyquinoline derivatives (2a-h).

\begin{tabular}{ccccc}
\hline Substances & R & Yield (\%) & Time (h) & m.p. $\left({ }^{\circ} \mathbf{C}\right)$ \\
\hline $\mathbf{2 a}$ & Methyl & 95 & 4 & $137-138^{4}$ \\
$\mathbf{2 b}$ & Ethyl & 82 & 8 & $98-99^{5}$ \\
$\mathbf{2 c}$ & Propyl & 75 & 10 & $70-71$ \\
$\mathbf{2 d}$ & Butyl & 62 & 24 & $56-57$ \\
$\mathbf{2 e}$ & i-Propyl & 60 & 15 & Oil ${ }^{4}$ \\
$\mathbf{2 f}$ & i-Butyl & 67 & 30 & $56-58$ \\
$\mathbf{2 g}$ & s-Butyl & 74 & 72 & Oil \\
$\mathbf{2 h}$ & $(1 E)$-prop-1-en-1-yl & 65 & 12 & $68-70$ \\
\hline
\end{tabular}

In general, these results showed that both reaction times and yields could be related to the size of the alkyl group attached to oxygen atom. As larger is the alkyl chain, more slowly is the reaction and poorer is the yield. Furthermore, all the compounds were identified by the spectral data. In general, IR spectra of 7-chloro-4-alkoxyquinoline derivatives (2a-h) showed the $\mathrm{C}-\mathrm{O}$ stretching vibrations at $1115-1124 \mathrm{~cm}^{-1}$. The nuclear magnetic resonance spectra $\left({ }^{1} \mathrm{H}\right.$ NMR) showed the six aromatic protons at 8.76-8.66, 8.20-8.15, 8.00-7.90, 7.51-7.60 and 7.08-7.01 ppm relative to protons of quinoline nucleus $(\mathrm{H}-2, \mathrm{H}-5, \mathrm{H}-8, \mathrm{H}-6$ and $\mathrm{H}-3$, respectively) and the corresponding aliphatic protons $(4.98-0.98 \mathrm{ppm})$. The ${ }^{13} \mathrm{C}$ NMR spectrum showed the C-O (C-4) signals at 161.6-159.7 and $\mathrm{C}=\mathrm{N}(\mathrm{C}-2)$ signals at 153.1$153.0 \mathrm{ppm}$.

\section{Biological evaluation}

The antimycobacterial activities of the derivatives $\mathbf{2 a - h}$ were assessed against M. tuberculosis ATCC $27294^{7}$ using the microplate Alamar Blue assay (MABA) ${ }^{8}$ (Table 2). This nontoxic methodology uses a thermally-stable reagent and shows good correlation with proportional and BACTEC radiometric methods ${ }^{9,10}$.

Furthermore, all the active compounds were selected for evaluation of their cytotoxicities against the human hepatoma (HepG2). The cellular viability in the presence and absence of the test compounds was determined using the Mosman's MTT (3-(4.5-demethylthylthiazol-2-yl)-2.5-dimethyltetrazolium bromide; Merck) microcultured tetrazolium assay ${ }^{11}$. The results are expressed as the minimum lethal dose that killed $50 \%$ of the cells $\left(\mathrm{MLD}_{50}\right)$ in $\mu \mathrm{M}$ are listed in Table 2 . The relative selectivity (selective index) of these compounds against $M$. tuberculosis compared to HepG2 was calculated based on MLD $50 /$ MIC ratios (Table 2).

In general, it was observed that the biological activity of this series also could be related to the increase of the size of the alkyl group attached to oxygen atom, which can be see when the compounds 2a-e are compared. Besides, the ramification of alkyl chain also could be important since the presence of branched alkyl groups (i-Butyl, 2g, s-Butyl, 2h) improve the biological activity when compared to a linear alkyl group (Butyl, 2e). Another important observation is that the presence of an unsaturated substituent improved the antimycobacterial activity, being the derivative $\mathbf{2} \mathbf{i}$ the most active of this series of compounds. 
Table 2. Antimycobacterial activity (MIC), cytotoxicity $\left(\mathrm{MLD}_{50}\right)$ and selective index of 7-chloro-4-alkoxyquinoline derivatives (2a-h).

\begin{tabular}{|c|c|c|c|c|}
\hline Substances & $\mathbf{R}$ & $\operatorname{MIC}(\mu \mathrm{M})$ & $\operatorname{MLD}_{50}(\boldsymbol{\mu M})$ & $\begin{array}{c}\text { Selective Índex } \\
\text { (SI) }\end{array}$ \\
\hline $2 \mathbf{a}$ & Methyl & 516.5 & 25826.4 & 50.0 \\
\hline $2 \mathrm{~b}$ & Ethyl & Resistant & ---- & ---- \\
\hline $2 c$ & Propyl & 225.5 & 992.3 & 4.4 \\
\hline $2 d$ & Butyl & 212.1 & 1400.1 & 6.6 \\
\hline $2 \mathbf{e}$ & i-Propyl & 225.5 & 315.7 & 1.4 \\
\hline $2 f$ & i-Butyl & 53.0 & 424.3 & 8.0 \\
\hline $2 \mathrm{~g}$ & s-Butyl & 106.1 & 721.3 & 6.8 \\
\hline $2 \mathrm{~h}$ & (1E)-prop-1-en-1-yl & 53.5 & 1240.9 & 23.2 \\
\hline EMB & & 15.3 & 25380.9 & 1659.5 \\
\hline
\end{tabular}

In regard to cytotoxicity evaluation, it was observed that these compounds were very cytotoxic when compared to ethambutol (EMB). The best SI value was observed for $2 \mathbf{a}$ followed by $\mathbf{2 h}$. EMB, our drug control, had the best SI value as expected. Compounds exhibiting SI lower than 20 (2c-h) were considered toxic ${ }^{12,13}$.

Although the biological results were not very significant, they are useful to identify the most important points for the antimycobacterial activity of the 7-chloro-quinoline derivatives. For example, when the series of 7-chloro-4-alkoxyquinoline derivatives (Series A, 2a-i) is compared to the 7-chloro-4-aminoquinoline derivatives (Series B, 1c-d, Table 3), it is important to be mentioned that the effect of the increase of the size of the alkyl chain on the biological activity is more relevant in the Series B. However, the compounds of Series B are, in general, less cytotoxic and more selective, which can indicate that the classic isosteric replacement $(\mathrm{NH} \times \mathrm{O})$ produced derivatives with the same potency, but with a better cytotoxic proflie.

Table 3. Comparison between the antimycobacterial activity (MIC), cytotoxicity (MLD $\left.{ }_{50}\right)$ and selective index of some derivatives of Series A (1)-d) and Series B (2b-d).<smiles>[R]Nc1ccnc2cc(Cl)ccc12</smiles>

\begin{tabular}{|c|c|c|c|c|c|c|c|c|}
\hline Series A & $\mathbf{R}$ & $\begin{array}{l}\text { MIC } \\
(\mu \mathrm{M}) \\
\end{array}$ & $\begin{array}{c}\text { MLD50 } \\
(\boldsymbol{\mu M}) \\
\end{array}$ & $\begin{array}{c}\text { Selective } \\
\text { Índex (SI) } \\
\end{array}$ & $\begin{array}{c}\text { Series } \\
\text { B } \\
\end{array}$ & $\begin{array}{l}\text { MIC } \\
(\mu \mathrm{M}) \\
\end{array}$ & $\begin{array}{c}\text { MLD50 }_{50} \\
(\mu \mathrm{M}) \\
\end{array}$ & $\begin{array}{c}\text { Selective } \\
\text { Index (SI) }\end{array}$ \\
\hline $1 b$ & Ethyl & 518.9 & 726.5 & 1,4 & $2 b$ & ---- & ---- & ---- \\
\hline 1c & Propyl & 226.6 & 362.5 & 1,6 & $2 c$ & 225.5 & 992.3 & 4.4 \\
\hline 1d & Butyl & 53.3 & 724.3 & 13,6 & 2d & 212.1 & 1400.1 & 6.6 \\
\hline
\end{tabular}




\section{Conclusion}

In summary, eight 7-chloro-4-alkoxyquinoline derivatives (Series B, 2a-h) were synthesized in good yields (60-92\%). Among them, four are new compounds (2d, 2f-h). The compounds of Series B were compared to 7-chloro-4-aminoquinoline derivatives (Series A) previously evaluated against TB by our research group and, in general, the classic isosteric replacement $(\mathrm{NH} \times \mathrm{O})$ produced derivatives with the same potency, but with a better cytotoxic profile. Therefore, this study is important information about the structure-activity of 7-chloroquinoline analogs and could provide a better direction in the management of antimycobacterial activity of this class of compounds.

\section{Acknowledgments}

The authors would like to thank to CNPq, FAPERJ and the Program for Technological Development in Tools for Health-PDTIS-FIOCRUZ for use of its facilities.

\section{References}

1- WHO Global TB report 2011: http://www.who.int/tb/publications/global_report/en/ (Accessed: February, 10, 2015).

2- A. L. P. Candéa, M. L. Ferreira, K. C. Pais, L. N. F. Cardoso, C. R. Kaiser, M. G. M. O. Henriques, M. C. S. Lourenço, F. A. F. M. Bezerra, M. V. N. de Souza. Bioor. Med. Chem. Lett., 2009, 19, 6272-6274.

3- S. S. Ravichandran; S. A. Dhanaraj; H. Rajak; S. Kumar. W.J.P.P.S., 2014, 3, 1072-1082.

4- N. D. Heindel, S. A. Fine. J. Heterocycl. Chem., 1969, 6, 961.

5- L. R. Gomes, J. N. Low, J. L. Wardell, L. N. F. Cardoso, M. V. N. De Souza, Acta Crystallogr., Sect. C: Cryst. Struct. Commun., 2013, 69, 191-194.

6- F. Denizot, R. Lang. J. Immunol. Meth., 1986, 89, 271-277.

7- J. Canetti, E. Rist, R. Grosset, Revue Tuberc. Pneumol., 1963, 27, 217-272.

8- S. G. Franzblau, R. S. Witzig, J. C. McLaughlin, P. Torres, G. Madico, A. Hernandez, M. T. M. B. Degnan, V. K. Cook, R. M. Quenzer, R. H. Ferguson, J. Clin. Microbiol., 1998, 36, 362-366.

9- J. D. Vanitha, C. N. Paramasivan. Diagn. Microbiol. Infect. Dis., 2004, 49, 179-182.

10-R. S. Reis, I. Neves Jr., S. L. S. Lourenço, L. S. Fonseca, M. C. S. Lourenço, J. Clin. Microbiol., 2004, 42, 2247-2248.

11-T. Mossmann. J. Immunol. Meth., 1983, 65, 55-63.

12-J. R. Loset R. Brun, T. Wenzler, M. Kaiser, V. Yardley, 2009, DNDi and Pan-Asian Screening Network 1-74.

13-S. Nwaka, A. Hudson. Nature Rev. Drug Discov., 2006, 5, 941-955. 